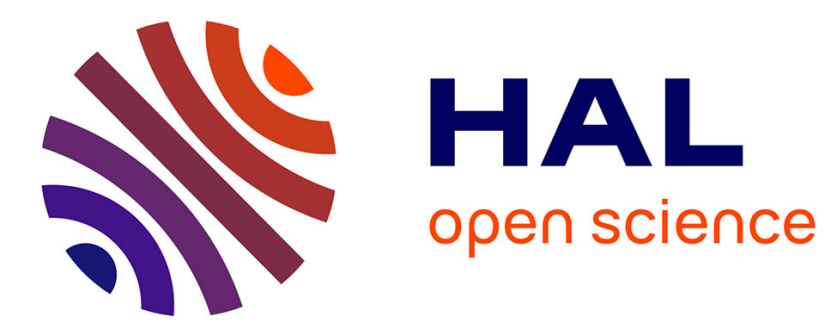

\title{
Proteolysis of casein micelles by Pseudomonas fluorescens CNRZ 798 contributes to the destabilisation of UHT milk during its storage
}

Gaucher, Tanguy, Fauquant, Jardin, Rousseau, Robert, Madec, Gaucheron

\section{- To cite this version:}

Gaucher, Tanguy, Fauquant, Jardin, Rousseau, et al.. Proteolysis of casein micelles by Pseudomonas fluorescens CNRZ 798 contributes to the destabilisation of UHT milk during its storage. Dairy Science \& Technology, 2011, 91 (4), pp.413-429. 10.1007/s13594-011-0019-4 . hal-00930578

\section{HAL Id: hal-00930578 https://hal.science/hal-00930578}

Submitted on 1 Jan 2011

HAL is a multi-disciplinary open access archive for the deposit and dissemination of scientific research documents, whether they are published or not. The documents may come from teaching and research institutions in France or abroad, or from public or private research centers.
L'archive ouverte pluridisciplinaire HAL, est destinée au dépôt et à la diffusion de documents scientifiques de niveau recherche, publiés ou non, émanant des établissements d'enseignement et de recherche français ou étrangers, des laboratoires publics ou privés.

$$
\text { Copyright }
$$




\title{
Proteolysis of casein micelles by Pseudomonas fluorescens CNRZ 798 contributes to the destabilisation of UHT milk during its storage
}

\author{
Isabelle Gaucher • Gaëlle Tanguy • Jacques Fauquant • Julien Jardin • \\ Florence Rousseau • Benoît Robert • Marie-Noëlle Madec • Frédéric Gaucheron
}

Received: 10 August 2010 /Revised: 13 January 2011 / Accepted: 13 January 2011 / Published online: 14 April 2011

(C) INRA and Springer Science+Business Media B.V. 2011

\begin{abstract}
Among the incriminating factors in the destabilisation of ultra-hightemperature (UHT) milk during storage, the heat-resistant proteases of Pseudomonas are considered to play a role. The objective of this work was to study the consequences of contamination of raw skim milk with Pseudomonas fluorescens CNRZ 798 on the stability of the corresponding UHT milk during storage. After 92 days, milk destabilisation was determined by the presence of a gelled sediment and low value to phosphate test $(2.4 \mathrm{~mL}$ for control against $0 \mathrm{~mL}$ of phosphate solution for milk contaminated before UHT treatment) and the presence of aggregates. For the UHT control milk and UHT milk manufactured from raw skim milk contaminated with $P$. fluorescens, an increase in the size of the casein micelles (205 and $332 \mathrm{~nm}$, respectively), a decrease in the zeta potential $(-16.6$ and $-14.0 \mathrm{mV}$, respectively) and decrease in the level of hydration (2.00 and $1.55 \mathrm{~g}$ of water per gramme of dried pellet, respectively) were detected. The increase in $\mathrm{pH} 4.6$-soluble nitrogen and trichloroacetic acid-soluble nitrogen content for UHT milk previously contaminated were ten- and fivefold higher than those for control milk, respectively. The trichloroacetic acid-soluble nitrogen fraction of the milk contaminated before treatment contained 118, 22, 4 and 9 peptides from $\beta-, \alpha_{\mathrm{s} 1^{-}}, \alpha_{\mathrm{s} 2^{-}}$and $\mathrm{k}$-caseins in comparison to only 22, 19, 6 and 4 peptides for the control milk. This study showed that destabilisation of UHT milk was due to proteolysis of casein micelles.
\end{abstract}

I. Gaucher $\cdot$ G. Tanguy $\cdot$ J. Fauquant $\cdot$ J. Jardin $\cdot$ F. Rousseau $\cdot$ B. Robert $\cdot$ M.-N. Madec $\cdot$

F. Gaucheron $(\square)$

UMR1253, Science et Technologie du Lait et de l'Euf, INRA, F-35042 Rennes, France

e-mail: frederic.gaucheron@rennes.inra.fr

I. Gaucher $\cdot$ G. Tanguy $\cdot$ J. Fauquant $\cdot$ J. Jardin $\cdot$ F. Rousseau $\cdot$ B. Robert $\cdot$ M.-N. Madec $\cdot$

F. Gaucheron

UMR1253, Science et Technologie du Lait et de l'Euf, AGROCAMPUS OUEST, F-35042 Rennes, France 


\section{摘要-贬藏期间荧光假单胞菌 CNRZ 798 水解酪蛋白胶束导致 UHT 奶的不稳定}

摘要 假单胞菌产生的耐热性蛋白酶是造成 UHT 奶伧藏期间不稳定最主要的因素 以污染了苂 光假单胞菌 CNRZ 798 的脱脂乳为原料生产 UHT 奶 (实验组), 研究其在败藏期间的稳定性 该 UHT奶陉藏 92 天后, 就出现了不稳定现象, 能够检测到凝胶沉淀和出现絮凝物 以污染了荧光 假单胞菌 CNRZ 798 的奶样为对照组 (UHT 处理前), 对照组的磷酸盐值为 $0 \mathrm{~mL}$, 保存 92 天, 实验 组的磷酸盐试验值为 2.4 。对照组和实验组的酪蛋白胶束直径分别为 $205 \mathrm{~nm}$ 和 $332 \mathrm{~nm}$, 而它 们的 zeta 电位分别为 -16.6 和 $-14.0 \mathrm{mV}$, 水合能力分别为 $2.00 \mathrm{~g} \cdot \mathrm{g}^{-1}$ 和 $1.55 \mathrm{~g} \cdot \mathrm{g}^{-1}$ (水/干酪蛋白 胶束)。实验组中 $\mathrm{pH}-4.6$ 可溶性氮和三氯乙酸酸溶性氮的含量分别是对照组的 10 倍和 5 倍。在 实验组中, 从三氯乙酸酸溶性氮组分中检测到了由 $\beta-、 \alpha_{\mathrm{s} 1}-、 \alpha_{\mathrm{s} 2^{-}}$和 $k$-酪蛋白水解产生的 118、22、4 和 9 肽, 而在对照组中只检测到 22、19、6 和 4 肽。因此, 可以证明酪蛋白胶束 的水解是造成UHT奶不稳定的主要原因。

Keywords Casein micelles $\cdot$ Stability $\cdot$ Proteolysis $\cdot$ Physico-chemical characteristics · UHT treatment

关键词 酪蛋白胶束·稳定性·蛋白质水解·物理化学特性·UHT 处理

\section{Introduction}

Sterilization at ultra-high temperature (UHT, $140{ }^{\circ} \mathrm{C} / 4 \mathrm{~s}$ ) combined with aseptic packaging provides a microbiologically safe milk for the consumer. Even though this milk is considered sterile, different physico-chemical and enzymatic changes occur during storage (Gaucher et al. 2008; Walstra et al. 2006). Sometimes, these changes can lead to destabilisation of the product, such as gelation or sedimentation of UHT milk, which is observed directly in the packaging or after heating by the consumer (Gaucher et al. 2009; Topçu et al. 2006). Different causes and mechanisms have been proposed to explain this defect, and proteolysis has often been suspected (Datta and Deeth 2001; McMahon 1996). Proteolysis has been attributed to endogenous enzymes such as plasmin or exogenous enzymes such as bacterial proteases (Datta and Deeth 2003). Psychrotrophic bacteria, and especially the Pseudomonas sp., are particularly incriminated in this destabilisation. The Pseudomonas genus consist of a large heterogenous group of organisms, and most researches have focused on their phenotypic (biotype, proteolytic and lipolytic profiles) and genotypic (plasmid profiles and ribotypes) characteristics (Wang and Jayaro 2001). In addition, these bacteria can grow at low temperatures and release heat-resistant proteases (Adams et al. 1975; Cousin 1982; Fairbairn and Law 1986; Richardson et al. 1978; Sørhaug and Stepaniak 1997). For example Griffiths et al. (1981) showed that proteases of different strains of Pseudomonas were able to retain about $20-40 \%$ of their activity after heat treatment to $140{ }^{\circ} \mathrm{C}$ for $5 \mathrm{~s}$. Liao and McCallus (1998) indicated that over $20 \%$ of the enzyme activity persisted after a boiling for $10 \mathrm{~min}$. Rajmohan et al. (2002) reported that a protease isolated from Pseudomonas fluorescens was heat stable and retained activity even after treatment to $121{ }^{\circ} \mathrm{C}$ for $20 \mathrm{~min}$. More recently, Marchand et al. (2008) showed that heating milk samples to $95{ }^{\circ} \mathrm{C}$ for $8.45 \mathrm{~min}$ resulted in a residual heat-resistant proteolytic activity of $73 \%$.

The caseinolytic potential of these proteases is highly variable and strain dependent (Dufour et al. 2008). Some studies have been performed to understand 
the proteolytic activities on the milk proteins and especially on the casein molecules. Koka and Weimer (2000) indicated that a protease isolated from P. fluorescens RO98 preferentially hydrolysed $\mathrm{K}$-casein in artificial casein micelles. With the same objective, Costa et al. (2002) showed that an extract of $P$. fluorescens RV10 culture proteolysed $\mathrm{K}$-casein and $\beta$-casein. More recently, Nicodème (2006) characterized an extracellular protease from Pseudomonas aureofaciens LBSA1 and identified some peptidic bonds which had been cleaved by this enzyme on different purified casein molecules. Globally, this enzyme can hydrolyse all casein molecules. However, all these studies were only performed on model systems with more or less purified enzyme and no precise results have been described on milk.

The objective of this study was to evaluate the consequences on the voluntary contamination of raw skim milk with $P$. fluorescens CNRZ 798 on the stability of the corresponding UHT milk during 92 days of storage with special attention being paid to the physico-chemical properties and biochemical composition of casein micelles. To reach this objective, raw skim milk was first microfiltered to remove somatic cells and bacteria and then inoculated with $P$. fluorescens. Finally, this milk was sterilized by an UHT treatment and stored for 92 days at $20^{\circ} \mathrm{C}$. During this storage period, the stability of the UHT milk was evaluated by: (1) the value obtained with the phosphate test and the determination of aggregates, (2) the measurement of size, charge and hydration of casein micelles and (3) the level of proteolysis by measuring the non-casein (NCN) and non-protein (NPN) nitrogen contents. The qualitative aspect of proteolysis was investigated by analysis of the peptide composition in the NPN filtrates by reversed phase liquid chromatography coupled to tandem mass spectrometry.

\section{Materials and methods}

\subsection{Bacterial strain used and growth conditions}

P. fluorescens CNRZ 798 came from the CNRZ collection located in the "Unité Bactéries Lactiques et Pathogènes Opportunistes (UBLO)", INRA Jouy en Josas, France. These bacteria were chosen because they may be responsible for the instability of UHT milk as reported in the literature and according to dairy industry. More precisely, P. fluorescens CNRZ 798 was chosen as this strain has the capacity to hydrolyse casein molecules (preliminary results not shown in this study). P. fluorescens CNRZ 798 was stored at $-20{ }^{\circ} \mathrm{C}$ in Brain Heart Infusion (BHI) supplemented with $15 \%(v / v)$ glycerol. Before use, culture was revived from frozen stocks, propagated by three successive transfers in BHI supplemented with $1 \%(w / w)$ yeast extract, incubated at $30{ }^{\circ} \mathrm{C}$ for 2 days. Cultures were finally propagated in commercial UHT milk and incubated at about $20{ }^{\circ} \mathrm{C}$ for 3 days, then at $4{ }^{\circ} \mathrm{C}$ for 3 days without agitation.

\subsection{Milk processing}

Fresh bulk raw milk was obtained from a local Brittany farm. Raw milk was skimmed using a cream separator (Elecrem, Châtillon, France) at $50{ }^{\circ} \mathrm{C}$ and then microfiltered by a TIA microfiltration unit (TIA, Bollène, France) equipped with a ceramic membrane Sterilox (reference 1P1940, membrane area $=0.24 \mathrm{~m}^{2}, 1.02 \mathrm{~m}$ 
long, pore size $=0.8 \mu \mathrm{m}$, temperature of microfiltration $=50^{\circ} \mathrm{C}$, Pall-Exekia, Bazet, France). Microfiltration was performed to remove somatic cells and bacteria from the milk in order to minimize their contribution to the proteolysis of milk. Microfiltered milk had reduced the somatic cell count from $6.7 \times 10^{4}$ somatic cells $\mathrm{mL}^{-1}$ and $2.6 \times 10^{3}$ colony-forming units (CFU) per millilitre to $1.2 \times 10^{4}$ somatic cells $\mathrm{mL}^{-1}$ and less than $10 \mathrm{CFU} \cdot \mathrm{mL}^{-1}$. Following refrigeration, microfiltered milk was divided into two parts: one served as the control milk and the second was incubated for $2 \mathrm{~h}$ at $4{ }^{\circ} \mathrm{C}$ in the presence of $2.2 \times 10^{5} \mathrm{CFU} \cdot \mathrm{mL}^{-1}$ of $P$. fluorescens CNRZ 798. Heat treatment of both milks (with or without $P$. fluorescens) was performed with an indirect UHT processing system (Microthermics UHT/HTST Lab 25 EDH, Microthermics, Inc., Raleigh, NC, USA). Milk was preheated to $90{ }^{\circ} \mathrm{C}$ in a first tubular heat exchanger and heated to $140{ }^{\circ} \mathrm{C}$ in a second heat exchanger for 4 s. After immediate cooling to $17{ }^{\circ} \mathrm{C}$, glass bottles (volume $250 \mathrm{~mL}$ ) were aseptically filled. The bottles were stored at about $20^{\circ} \mathrm{C}$ in the dark before analysis. The concentration of protein, lactose and residual fat for both UHT milks was determined by an infrared spectrometer Lactoscope (Delta Instruments, Drachten, Netherlands), and were $30.4,50.0$ and $1.3 \mathrm{~g} \cdot \mathrm{kg}^{-1}$, respectively.

\subsection{Physico-chemical characterization of UHT milks during storage}

Both UHT milks were analysed at different times during 92 days of storage at room temperature. For some analyses, milks were analysed only at 0 and 92 days of storage. Before each analysis, the absence of bacterial contamination in UHT milk was checked by enumeration on a plate count agar medium incubated for 3 days at $30{ }^{\circ} \mathrm{C}$. For further analyses on the milk, thiomersal 0.03\% (w/v) (Sigma, Saint Louis, USA) was added to prevent microbial growth during analyses. The $\mathrm{pH}$ of all UHT milks fluctuated between 6.60 and 6.71 during storage.

\subsubsection{Phosphate stability}

For the phosphate test, the protocol described by Ramsdell et al. (1931) and Gaucher et al. (2008) was followed. Milks $(10 \mathrm{~mL})$ were placed in sealed Pyrex tubes and volumes of $\mathrm{KH}_{2} \mathrm{PO}_{4}(0.5 \mathrm{M})$ (Panreac Quimica SA, Barcelona, Spain) were gradually added to each sample. After mixing, samples were heated to $100 \pm 1{ }^{\circ} \mathrm{C}$ for $10 \mathrm{~min}$. After heat treatment, the smallest volume of phosphate solution which induced milk destabilisation was recorded. The experimental error was about $\pm 0.1 \mathrm{~mL}$.

\subsubsection{Characterization of milk particles}

The size distribution of milk particles was determined using a Mastersizer 2000 granulometer (Malvern Instruments Ltd, Worcestershine, UK). Milks were directly injected into the dispersion cell containing deionized water under agitation at 1,500 rpm. The refractive indexes were 1.333 and 1.57 for water and casein micelles, respectively (Griffin and Griffin 1985). The experimental error was about $\pm 5 \mathrm{~nm}$.

Hydrodynamic particle diameters of casein micelles were also measured by dynamic light scattering on a Zetasizer Nano ZS (Malvern Instruments, Worcestershire, United Kingdom). Milks were previously diluted 1/100 in their corresponding 
ultrafiltrate obtained by centrifugation of milk at $1,800 \times \mathrm{g}$ for $2 \mathrm{~h}$ on a Vivaspin 20 concentrator (molecular mass cut-off, $10 \mathrm{~kg} \cdot \mathrm{mol}^{-1}$ ) (Vivascience, Palaiseau, France). The refractive indexes for casein micelles and ultrafiltrates were 1.570 and 1.348 , respectively. The viscosity of ultrafiltrate at $20{ }^{\circ} \mathrm{C}$ was $1.1868 \times 10^{-3} \mathrm{~Pa} \cdot \mathrm{s}$. Measurements were performed at a scattering angle of $173^{\circ}$ and a wavelength of $633 \mathrm{~nm}$. The average diameter was obtained from the intensity distribution. The experimental error was about $\pm 5 \mathrm{~nm}$.

Zeta potential of casein micelles was determined using the same equipment (Zetasizer Nano ZS) after milk dilution in their corresponding ultrafiltrates and keeping the same refractive indexes and the same viscosity for the dispersant solution. The applied voltage was set at $50 \mathrm{~V}$ and the dielectric constant was 80 . Measurement of the negative charge of micelles was based on electrophoretic mobility using Smoluchowski's equation (Smoluchowski 1917). The experimental error was about $\pm 1 \mathrm{mV}$.

Hydration of casein micelles corresponded to the water content of the pellet obtained after ultracentrifugation of milk for $1 \mathrm{~h}$ at $100,000 \times \mathrm{g}$ at $20{ }^{\circ} \mathrm{C}$ (Sorvall Discovery 90 SE, Sorvall, Courtaboeuf, France). Pellets were weighed and dried for $7 \mathrm{~h}$ at $103{ }^{\circ} \mathrm{C}$. The difference in the weights before and after drying corresponded to the water content of the ultracentrifuged pellet and was expressed in grammes of water per gramme of dried pellet. The experimental error was about $\pm 0.03 \mathrm{~g} \cdot \mathrm{g}^{-1}$ of dried pellet.

\subsubsection{NCN and NPN contents}

The NCN and NPN contents corresponding to the soluble fraction at $\mathrm{pH} 4.6$ and soluble fraction after precipitation with $12 \%$ trichloroacetic acid, respectively, were determined using the Kjeldhal method according to FIL-IDF standard 20B (IDF 2001). The converting factors used for NCN and NPN were 6.3 and 3.6, respectively (Karman and Van Boekel 1986). The experimental error was about $\pm 0.1 \mathrm{~g}$ of nitrogen expressed in protein per kilogramme.

\subsubsection{Separation and identification of peptides present in the NPN fraction by RP-HPLC coupled to ESI-MS/MS}

The separation and identification of peptides were performed only once for four samples (UHT milk control and UHT milks manufactured from raw skim milk contaminated with $P$. fluorescens after 0 and 92 days of storage).

The first step in the purification and concentration was performed using Waters Sep-Pack ${ }^{\circledR}$ Vac cartridges as reported by Gaucher et al. (2008). After this step, samples were redissolved in $1 \mathrm{~mL}$ distilled water containing $0.1 \%$ trifluoroacetic acid (TFA).

A volume of $20 \mu \mathrm{L}$ was injected into the chromatographic system coupled to electrospray ionization tandem mass spectrometry (ESI-MS/MS). Mass spectrometry (MS) experiments were performed using an on-line liquid chromatography tandem mass spectrometry (MS/MS) setup using an LC Packings Micro LC system (Dionex) fitted to a QSTAR XL (MDS SCIEX, Ontario, Canada) equipped with a nanoelectrospray ion source (ESI) (Proxeon Biosystems A/S, Odense, Denmark). 
The instrument was calibrated with a multi-point calibration using fragment ions that resulted from the collision-induced decomposition of a peptide from $\beta$-casein, $\beta$-CN (193-209). A preliminary sample concentration step was performed on a reversephase column PepMap $100(\mathrm{C} 18,5 \mu \mathrm{m}, 300 \mu \mathrm{m}$ inner diameter (ID) $\times 5 \mathrm{~mm}$ length (L)) (LC Packings, Dionex, Amsterdam, Netherlands). Separation was performed on a reverse-phase column PepMap (C18, $3 \mu \mathrm{m}, 75 \mu \mathrm{m}$ ID $\times 150 \mathrm{~mm} \cdot \mathrm{L})$ (LC Packings, Dionex, Amsterdam, Netherlands) at room temperature, using solvent A $(2 \%(v / v)$ acetonitrile, $0.08 \%(v / v)$ formic acid and $0.01 \%(v / v)$ TFA in deionized water) and solvent B $(95 \%(v / v)$ acetonitrile, $0.08 \%(v / v)$ formic acid and $0.01 \%(v / v)$ TFA in deionized water). A linear gradient from $10 \%$ to $50 \%$ of solvent B in 80 min was applied for the elution at a flow rate of $0.2 \mu \mathrm{L} \cdot \mathrm{min}^{-1}$. Eluted peptides were directly electrosprayed into the mass spectrometer operating in positive mode. The spectrometer operated in data-dependent mode and spectra were collected in the selected mass range 300-1,500 and 60-2,000 m/z for MS and MS/MS, respectively.

To identify peptides, all data (MS and MS/MS) were submitted to MASCOT (v.2.2). The search was performed against a homemade database dealing with major milk proteins which represents a portion of the Swissprot database (http://www. uniprot.org). For each peptide identified, a minimum MASCOT score corresponding to a $p$ value below 0.05 was considered as a prerequisite for peptide validation with a high degree of confidence.

\section{Results}

\subsection{Evolution of the stability of UHT milks during storage}

Just after UHT treatment, the phosphate stability value was $2.3 \mathrm{~mL}$ of phosphate for both UHT milks (Fig. 1). For UHT control milk, the phosphate stability increased during the first month of storage and then decreased to reach a value of $2.4 \mathrm{~mL}$ of $\mathrm{KH}_{2} \mathrm{PO}_{4}$ after 92 days of storage. For UHT milk manufactured from raw skim milk contaminated with $P$. fluorescens, the phosphate stability value decreased during storage, reaching $0.1 \mathrm{~mL}$ of phosphate at 64 days of storage. After 92 days of storage, visible sediment corresponding to about $5 \%$ of the total volume of the sample was detected.

Fig. 1 Phosphate stability during storage of control UHT milk (filled circle) and UHT milk manufactured from raw milk contaminated with $P$. fluorescens (filled square). Error bars correspond to experimental errors $( \pm 0.1 \mathrm{~mL})$

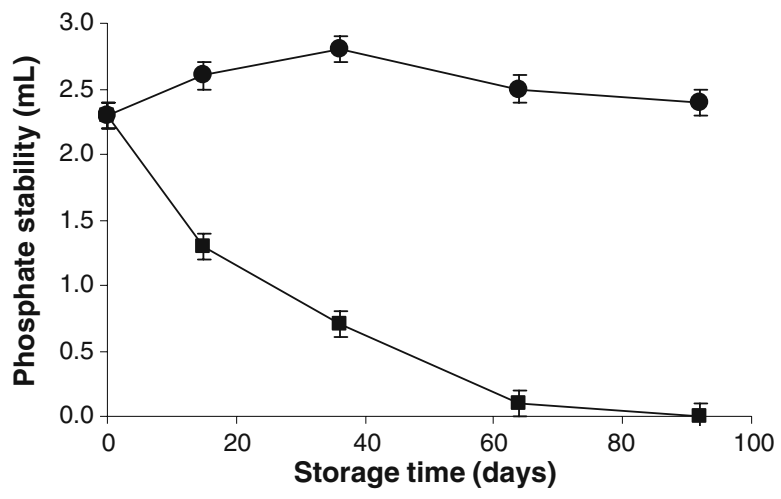


3.2 Evolution of the size, zeta potential and hydration of casein micelles during the storage of UHT milks

Regarding the particle size distribution of the UHT control milk, a monodisperse distribution was observed at all storage times. At 92 days of storage, this distribution ranged from 0.05 to $0.32 \mu \mathrm{m}$ (Fig. $2 \mathrm{a}$ ), with an average particle size of $0.2 \mu \mathrm{m}$. This population, as the milk had been skimmed, corresponded exclusively to casein micelles. For UHT milk manufactured from raw milk contaminated with $P$. fluorescens, three populations appeared after 92 days of storage (Fig. 2b). The particle size of the first population had a diameter of between 0.03 and $0.45 \mu \mathrm{m}$, the second between 0.45 and $1.42 \mu \mathrm{m}$ and the third between 2.83 and $6.32 \mu \mathrm{m}$. The first population, corresponding to casein micelles, was larger than in control milk. The nature of the two other populations was not determined but probably corresponded to the formation of aggregates.

The size and zeta potential of casein micelles were measured for both milks after 92 days of storage. For the UHT control milk, these values were $205 \pm 4 \mathrm{~nm}$ and $-16.6 \pm$ $0.8 \mathrm{mV}$, respectively. For UHT milk manufactured from raw milk contaminated with $P$. fluorescens, these values were $332 \pm 9 \mathrm{~nm}$ and $-14.0 \pm 0.5 \mathrm{mV}$, respectively.

Ultracentrifugation-pellet hydration was measured as a function of storage time (Fig. 3). Just after UHT treatment, this value was about $2.17 \pm 0.02 \mathrm{~g}$ of water per gramme of dried pellet. For the UHT control milk, the hydration value varied

Fig. 2 Particle size distribution of control UHT milk (a) and UHT milk manufactured from raw milk contaminated with $P$. fluorescens (b) after 92 days of storage
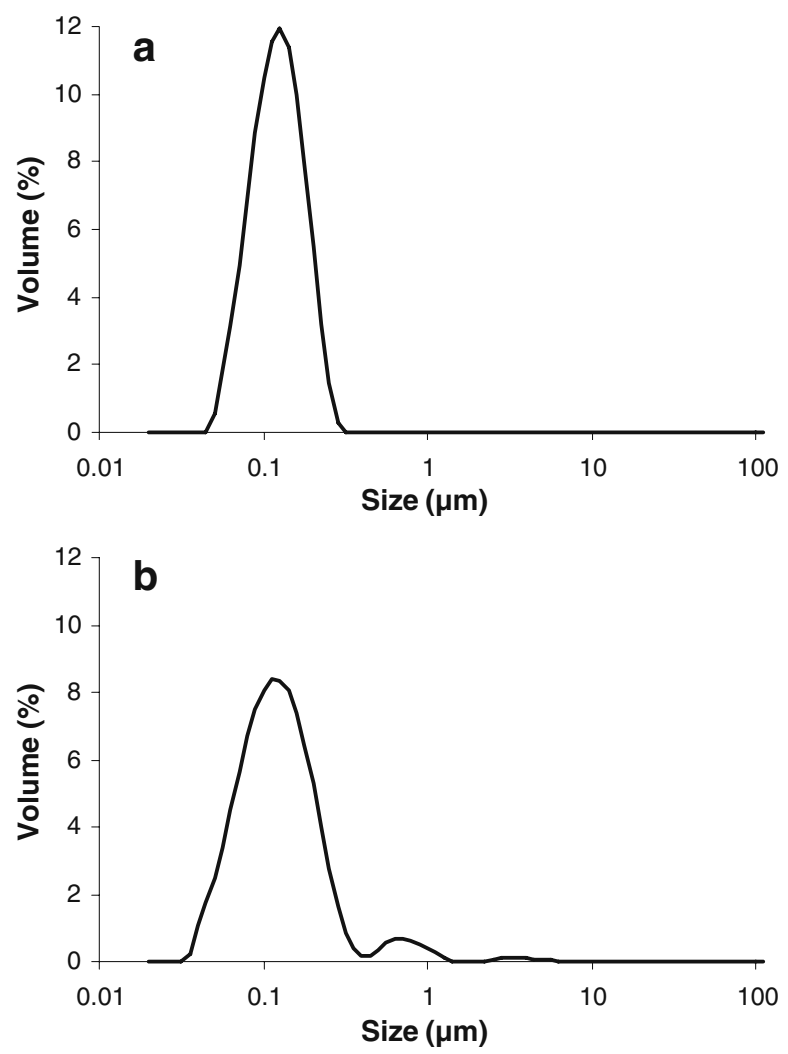
Fig. 3 Ultracentrifugation-pellet hydration during storage of control UHT milk (filled circle) and UHT milk manufactured from raw milk contaminated with $P$. fluorescens (filled square). Error bars correspond to experimental errors $( \pm 0.03 \mathrm{~g})$

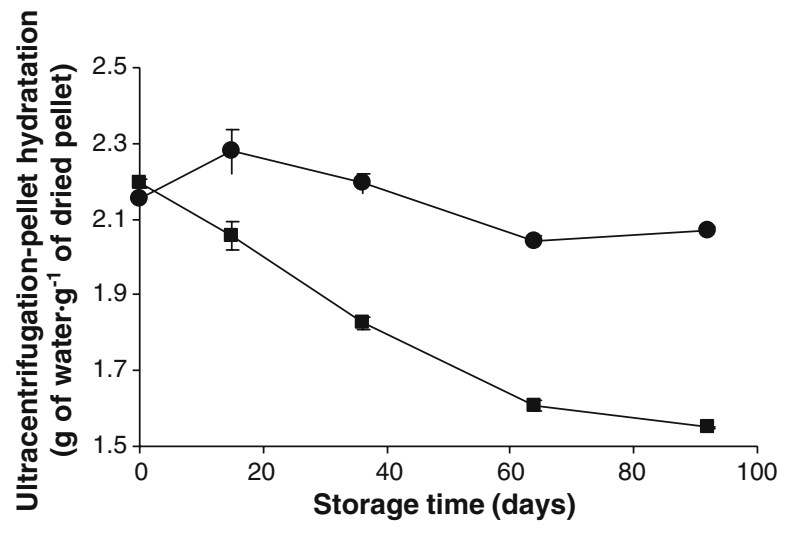

slightly during storage but remained above $2.0 \mathrm{~g}$ of water per gramme of dried pellet. For UHT milk manufactured from raw milk contaminated with $P$. fluorescens, this value decreased during the storage. After 92 days of storage, the value of ultracentrifugation-pellet hydration was $1.55 \mathrm{~g}$ of water per gramme of dried pellet.

\subsection{Evolution of the NCN and NPN contents during the storage of UHT milks}

The NCN content of UHT milk control was $3.7 \mathrm{~g} \cdot \mathrm{kg}^{-1}$ just after heat treatment (Fig. 4a). The UHT treatment denatured the whey proteins (especially immunoglobulins,

Fig. 4 Non-casein (a) and nonprotein (b) nitrogen contents during storage of control UHT milk (filled circle) and UHT milk manufactured from raw milk contaminated with P. fluorescens (filled square). Error bars corresponding to experimental error $( \pm 0.1 \mathrm{~g})$ are smaller than the symbols used
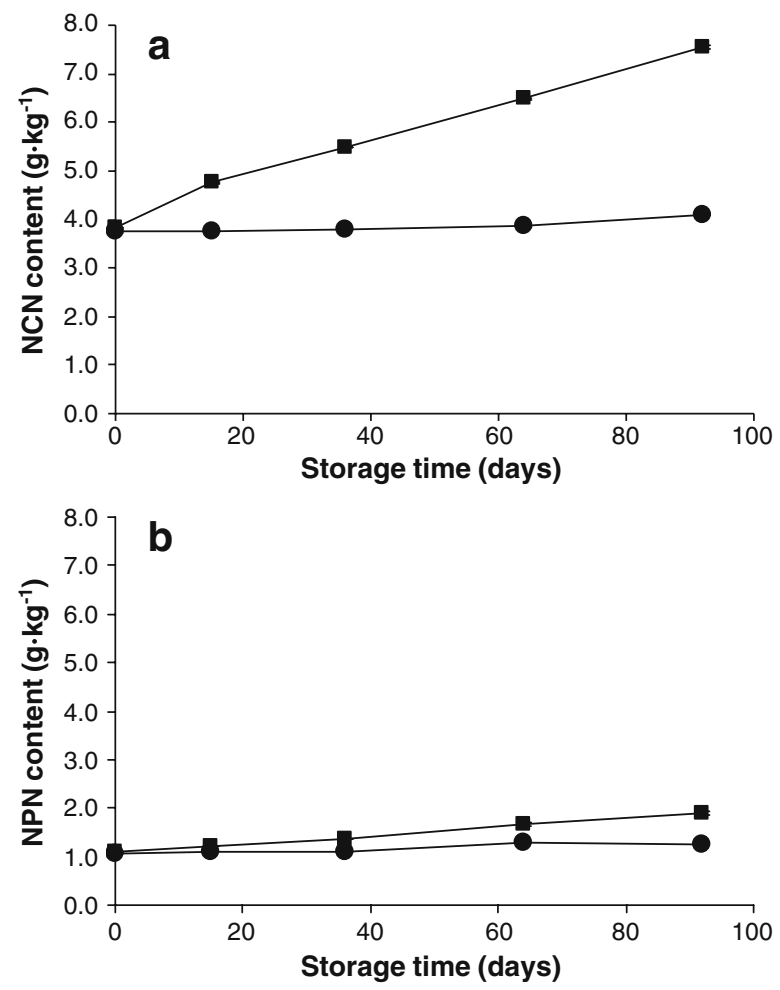
$\alpha$-lactalbumin and $\beta$-lactoglobulin) and their association with casein. This denaturation explains the low NCN content compared to the value obtained on raw milk (7-8 $\mathrm{g} \cdot \mathrm{kg}^{-1}$ ) (Gaucher et al. 2008). For the UHT control milk, the NCN content increased linearly during storage to reach a value of $4.1 \mathrm{~g} \cdot \mathrm{kg}^{-1}$ after 92 days of storage. For UHT milk manufactured from raw milk contaminated with $P$. fluorescens, the NCN content was $3.8 \mathrm{~g} \cdot \mathrm{kg}^{-1}$ just after heat treatment and increased to reach $7.5 \mathrm{~g} \cdot \mathrm{kg}^{-1}$ after 92 days of storage. The increase in NCN content for UHT milk previously contaminated with $P$. fluorescens was $3.7 \mathrm{~g} \cdot \mathrm{kg}^{-1}$, which was about tenfold higher than that detected in the UHT control milk.

The initial content of NPN for the UHT control milk was $1.07 \mathrm{~g} \cdot \mathrm{kg}^{-1}$ (Fig. 4b). This value corresponded to the presence of small molecules containing nitrogen like peptides, creatin, urea and free amino acids. It increased during storage and reached $1.24 \mathrm{~g} \cdot \mathrm{kg}^{-1}$ after 92 days of storage, corresponding to an increase of $0.17 \mathrm{~g} \cdot \mathrm{kg}^{-1}$. For UHT milk manufactured from raw milk contaminated with $P$. fluorescens, the initial NPN content was $1.08 \mathrm{~g} \cdot \mathrm{kg}^{-1}$ and reached $1.88 \mathrm{~g} \cdot \mathrm{kg}^{-1}$ after 92 days of storage. The increase in NPN content for this milk was $0.8 \mathrm{~g} \cdot \mathrm{kg}^{-1}$, which is fivefold higher than the NPN increase for UHT control milk.

3.4 Separation and identification of peptides present in the NPN fraction by RP-HPLC coupled to ESI-MS/MS

The chromatographic profiles of UHT control milk at 0 and 92 days of storage were (Fig. 5a) slightly different. The total intensity of the signal detection was slightly

Fig. 5 Chromatographic profiles of NPN filtrates obtained from control UHT milk (a) and UHT milk manufactured from raw milk contaminated with $P$. fluorescens (b) at 0 days (grey line) and 92 days (black line) of storage. The detection signal corresponds to total ion current (TIC)
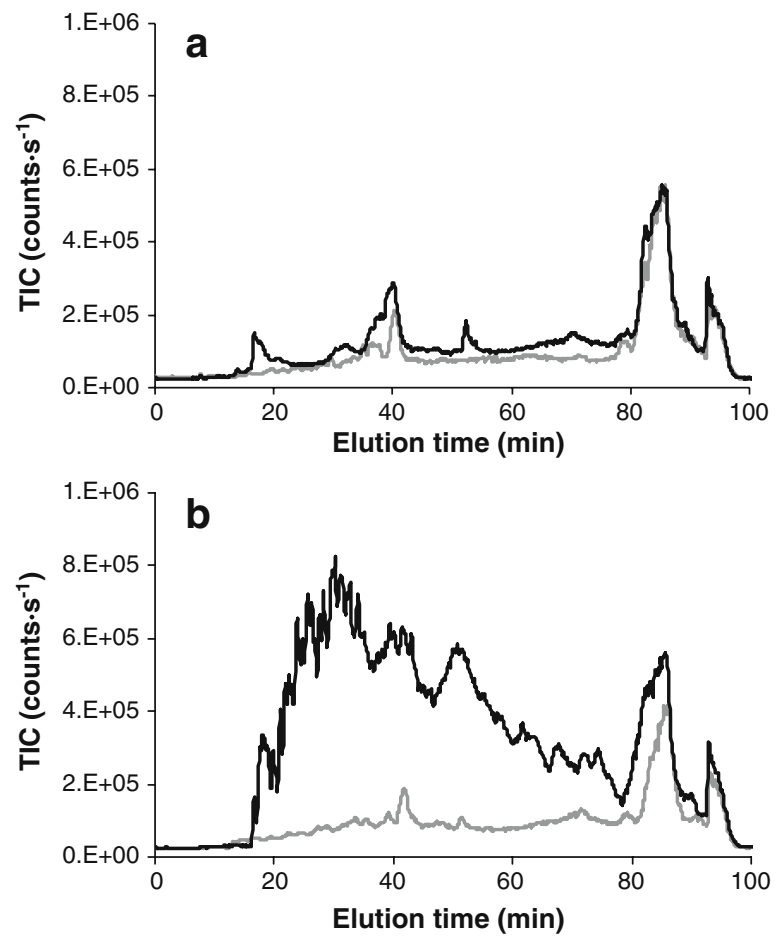
higher after 92 days of storage. Two small chromatographic peaks with retention times of about 17 and $53 \mathrm{~min}$ were observed. The chromatogram of UHT milk manufactured from raw milk contaminated with $P$. fluorescens at 92 days of storage was very different and more complex from those corresponding to 0 days of storage (Fig. 5b) and to UHT control milk at 0 and 92 days of storage (Fig. 5a). The total chromatographic area of this destabilised UHT milk was eightfold higher than the total chromatographic area obtained just after heat treatment of the UHT control milk. Through chromatographic separation, the identification of different peptides was obtained by ESI-MS/MS. The number of the peptides identified for both types of milk just after heat treatment and after 92 days of storage was reported in Table 1. Globally, the number of identified peptides was lower in the UHT control milk than in UHT milk manufactured from raw milk contaminated with $P$. fluorescens. For the UHT milk manufactured from raw milk contaminated with $P$. fluorescens stored for 92 days, peptides coming from $\beta->\alpha_{\mathrm{s} 1}->\mathrm{K}->\alpha_{\mathrm{s} 2}$-caseins were detected. The localization of the peptides in the sequence of $\beta-, \alpha_{\mathrm{s} 1^{-}}, \alpha_{\mathrm{s} 2^{-}}$and $\mathrm{k}$-caseins are presented in Figs. 6, 7, 8 and 9, respectively. For $\beta$-casein, several fragments contained in the sequence 29-69, 84-110 and 157-191 were observed. For $\alpha_{\mathrm{s} 1^{-}}$ casein, the peptides came mainly from the sequence $8-38$. For K-casein, it was mainly the sequence $105-123$ which was hydrolysed. No preferential part of the protein in the sequence of $\alpha_{\mathrm{s} 2}$-casein was detected.

\section{Discussion}

During the 92 days of storage, the microbiological analyses of UHT milk manufactured from raw milk contaminated with P. fluorescens and UHT control milk (without contamination) showed that sterility was maintained. Despite being sterile, the UHT milk manufactured from raw milk contaminated with $P$. fluorescens was destabilised. This instability was detected by visual observation and by the phosphate test (Fig. 1) classically used in dairy industry to detect instability (Gaucher et al. 2009). Laser granulometry confirmed this instability by determining the presence of aggregates (Fig. 2b in comparison with Fig.2a) only in the UHT milk manufactured from raw milk contaminated with $P$. fluorescens after storage for 92 days. The size of casein micelles also increased (205 and $332 \mathrm{~nm}$ for UHT control milk and UHT milk manufactured from raw milk contaminated with $P$. fluorescens

Table 1 Number of peptides identified in the NPN filtrate of UHT milk control and UHT milk manufactured from raw milk contaminated with Pseudomonas fluorescens

Peptides were identified by RP-HPLC coupled to ESI-MS/MS. Results are presented for each casein molecules
UHT milk UHT milk manufactured from raw control milk contaminated with $P$. fluorescens

\begin{tabular}{lrrrr}
\hline Days of storage & 0 & 92 & 0 & 92 \\
\hline$\beta$-casein & 9 & 13 & 22 & 118 \\
$\alpha_{\text {s1-casein }}$ & 18 & 11 & 19 & 22 \\
$\alpha_{\text {s2 }}$-casein & 10 & 9 & 6 & 4 \\
K-casein & 1 & 2 & 4 & 9 \\
Total & 38 & 35 & 51 & 153 \\
\hline
\end{tabular}


Control UHT milk after $0 \mathrm{~d}$ of storage

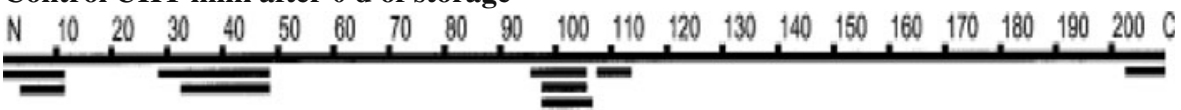

Control UHT milk after $92 \mathrm{~d}$ of storage

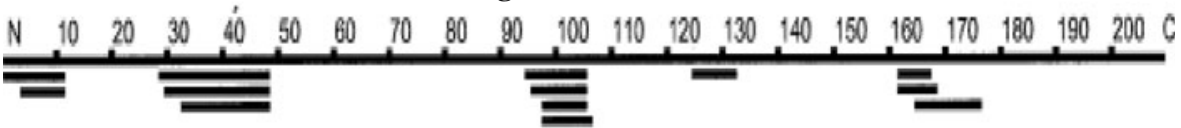

UHT milk contaminated with $P$. fluorescens after $0 \mathrm{~d}$ of storage

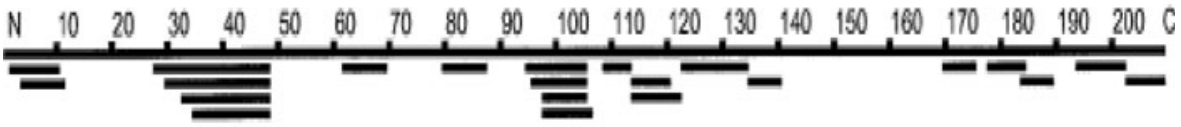

UHT milk contaminated with $\boldsymbol{P}$. fluorescens after $92 \mathrm{~d}$ of storage

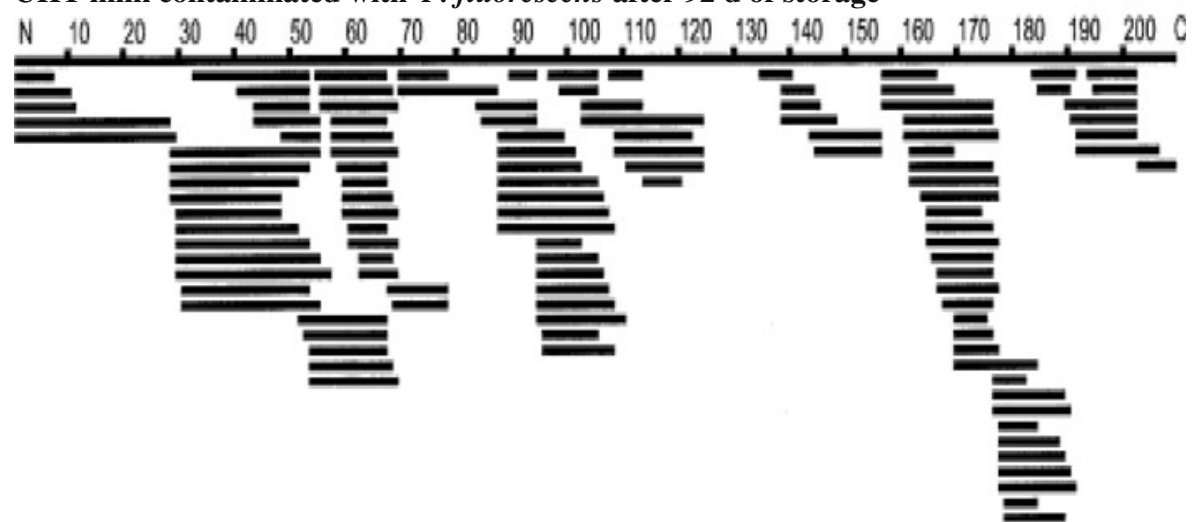

Fig. 6 Localization of the peptides in the sequence of $\beta$-casein. The peptides were identified in the NPN fraction by ESI-MS/MS. The cleaved peptide bonds are reported in Table 2

after 92 days of storage, respectively). This destabilisation of UHT milk suggested that residual enzymatic activities coming from $P$. fluorescens could be responsible for this instability. These results were in accordance with those showing that Pseudomonas species produced proteases which are resistant to high heat treatment and as a consequence result in biochemical degradation of milk and a limitation of its shelf life (Adams et al. 1975, 1976; Cousin 1982; Datta and Deeth 2001; Fairbairn and Law 1986; Griffiths et al. 1981; McMahon 1996; Mitchell and Ewings 1985; Richardson et al. 1978; Sørhaug and Stepaniak 1997). After 92 days of storage, the zeta potential of casein micelles was -16.6 and $-14.0 \mathrm{mV}$, and their hydration was 2.0 and $1.55 \mathrm{~g}$ of water per gramme of dried pellet for the UHT control milk and UHT milk manufactured from raw milk contaminated with $P$. fluorescens, respectively (Fig.3). A reduction in the zeta potential related to the release of peptides containing negatively charged groups such as glutamyl, aspartyl, phosphoseryl and glycosidic residues ( $\mathrm{N}$-terminal fragments of $\mathrm{K}$-casein) was also described by Gastaldi et al. (2003) and Crudden et al. (2005). The decrease of both these factors which are considered as stability factors of casein micelles can be related to changes in the structure of casein micelles induced by proteolysis. As a consequence of the decrease in the negative charge and hydration, repulsions between casein micelles decreased and resulted in aggregate formation (Fig. 2b). 
Lait UHT témoin Od O

Control UHT milk after $0 \mathrm{~d}$ of storage
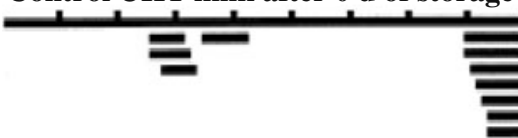

$\begin{array}{llllllllll}110 & 120 & 130 & 140 & 150 & 160 & 170 & 180 & 190 & \mathrm{C}\end{array}$

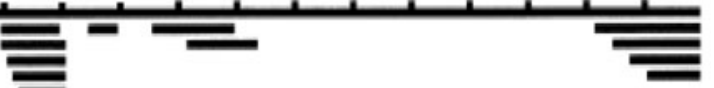

Lait UHT témoin 0 a $92 \mathrm{j}$

Control UHT milk after $92 \mathrm{~d}$ of storage

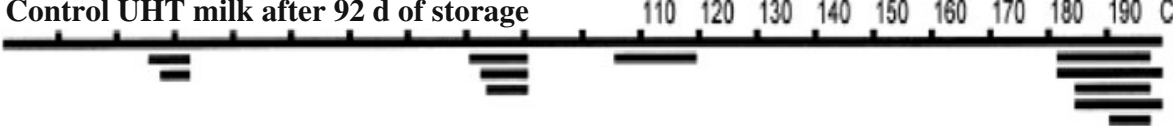

Lait UHT Jà Oj

UHT milk contaminated with $\boldsymbol{P}$. fluorescens after $0 \mathrm{~d}$ of storage

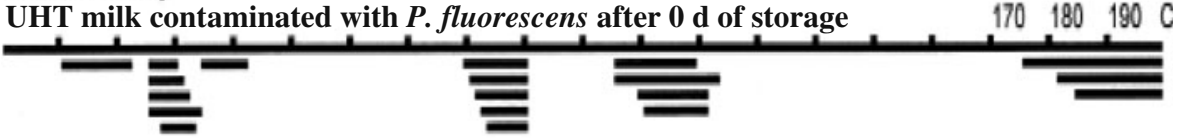

Lait UHT J A 92 j

UHT milk contaminated with $P$. fluorescens after $92 \mathrm{~d}$ of storage
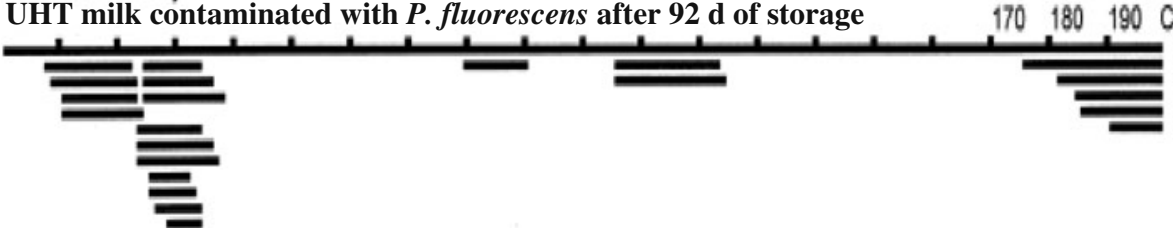

Fig. 7 Localization of the peptides in the sequence of $\alpha_{s 1}$-casein. The peptides were identified in the NPN fraction by ESI-MS/MS. The cleaved peptide bonds are reported in Table 2

Control UHT milk after $0 \mathrm{~d}$ of storage

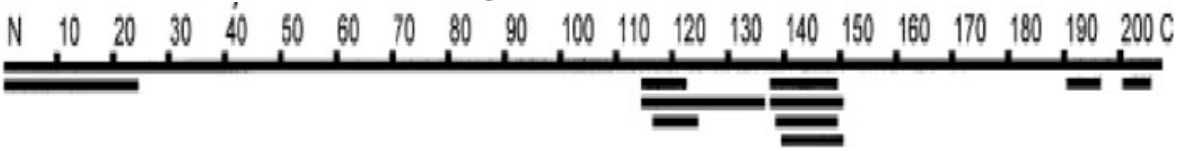

Control UHT milk after $92 \mathrm{~d}$ of storage

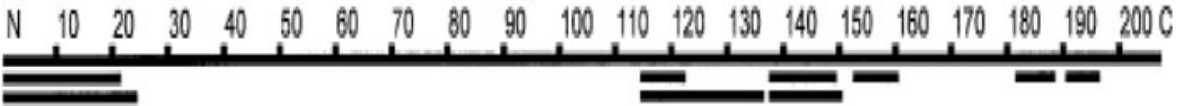

Lat UHT Jaj $0 \mathrm{j}$

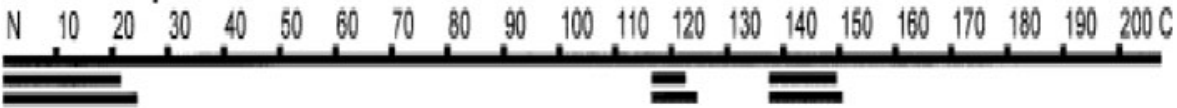

LaituHT Jà 92j

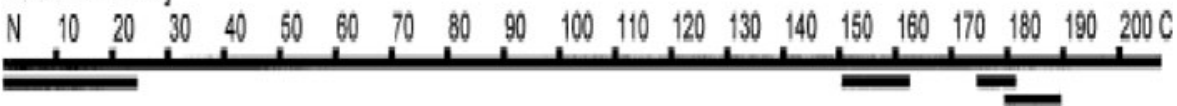

Fig. 8 Localization of the peptides in the sequence of $\alpha_{\mathrm{s} 2}$-casein. The peptides were identified in the NPN fraction by ESI-MS/MS. The cleaved peptide bonds are reported in Table 2 


\section{Control UHT milk after $0 \mathrm{~d}$ of storage

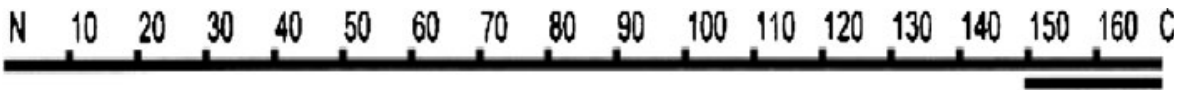

\section{Control UHT milk after $92 \mathrm{~d}$ of storage}

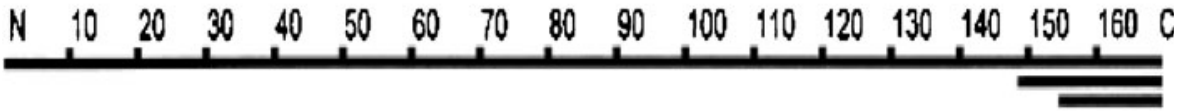

UHT milk contaminated with $P$. fluorescens after $0 \mathrm{~d}$ of storage

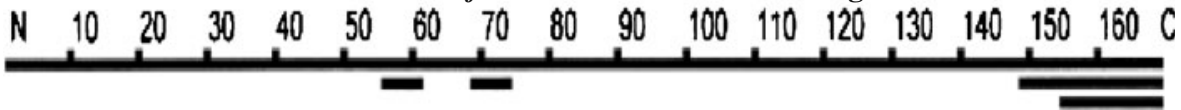

UHT milk contaminated with $P$. fluorescens after $92 \mathrm{~d}$ of storage

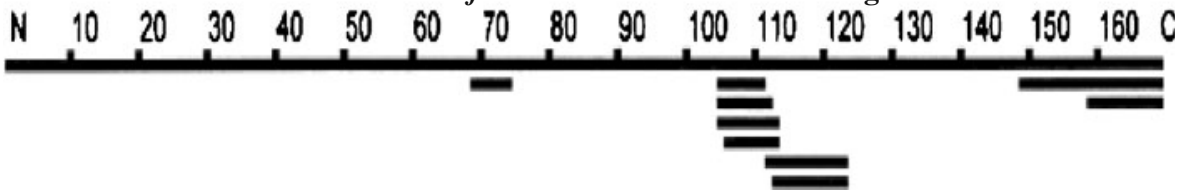

Fig. 9 Localization of the peptides in the sequence of $\mathrm{K}$-casein. The peptides were identified in the NPN fraction by ESI-MS/MS. The cleaved peptide bonds are reported in Table 2

The abnormal level of proteolysis, observed for the UHT milk manufactured from raw milk contaminated with $P$. fluorescens, was confirmed by the increase in NCN and NPN contents in this milk compared to the control milk (Fig. 4a, b). The increase in NCN content was greater than the increases in NPN content suggesting that proteolysis favoured the release of large casein fragments, present in the NCN fraction, but also small peptides and free amino acids present in the NPN fraction. The detection of abnormal levels of proteolysis during storage was in agreement with results reported by Celestino et al. (1997) and Rattray et al. (1997). The higher chromatographic area for UHT milk manufactured from raw milk contaminated with $P$. fluorescens compared to those determined in the UHT control milk confirmed this difference in the level of proteolysis between both types of milk (Fig. 5). Combining separation of individual peptides by the chromatographic method with ESI-MS/MS, the determination of the number of peptides in the NPN fraction (Figs. 6, 7, 8 and 9 for $\beta-, \alpha_{\mathrm{s} 1^{-}}, \alpha_{\mathrm{s} 2^{-}}$and $\mathrm{k}$-casein, respectively and Table 1) was performed. From the number of released peptides reported in Table 1, different comments can be made. For the UHT control milk sample, the apparent decrease in total peptides between day 0 (38 peptides detected) and day 92 (35 peptides) was not significant indicating that the level of proteolysis in UHT control milk during storage was relatively limited. Secondly, the increase in total peptide at day 0 between control (38 peptides) and contaminated milk (51 peptides) was probably due to the proteolytic action of Pseudomonas. Indeed, the time between contamination and UHT treatment was several hours, and this time was sufficient to achieve a significant level of proteolysis of the caseins. Thirdly, the number of peptides increased from 51 just after heat treatment to 153 peptides in the UHT milk manufactured from raw milk contaminated with $P$. fluorescens and stored for 92 days. In this milk, proteolysis occurred preferentially for $\beta->\alpha_{\mathrm{s} 1}->\mathrm{k}->\alpha_{\mathrm{s} 2}$-caseins. A similar order in the 
proteolysis of casein molecules has previously been reported for a study of unstable commercial milks (Gaucher et al. 2009). A total of 91 cleaved peptidic bonds were identified with 62, 18, 4 and 7 for $\beta-, \alpha_{\mathrm{s} 1^{-}}, \alpha_{\mathrm{s} 2^{-}}$and $\kappa$-casein, respectively (Table 2). Among these 91 peptides, 49 were also identified in a study by Nicodème (2006) which studied the action of extracellular proteinases of from $P$. aureofaciens LBSA1 on casein molecules. The presence of other cleaved peptidic bonds identified in this study but not by Nicodème (2006) could be explained by some differences in the experimental conditions. This study was performed on UHT milk (casein molecules are associated in casein micelles and were probably modified by the heat treatment) after storage for 92 days at $20{ }^{\circ} \mathrm{C}$. The study of Nicodème (2006) was performed using purified caseins and protease at $\mathrm{pH} 7.5$ and storage for 4 and $24 \mathrm{~h}$ at $37{ }^{\circ} \mathrm{C}$. In addition, the activity of the protease of their stain of Pseudomonas could be different in terms of specificity.

This study also showed a preferential hydrolysis of $\beta$-casein which was in agreement with previous results reporting on the proteolysis of stable (Gaucher et al. 2008) and unstable (Gaucher et al. 2009) UHT milks. This preferential proteolysis could be related to the particular position of this casein in the casein micelles and a higher concentration in the aqueous phase compared to the other casein molecules. However, other authors (Adams et al. 1976; Mitchell and Ewings 1985; Nicodème 2006) have shown that proteases of psychrotrophic bacteria hydrolysed all caseins but preferentially in the following order $\mathrm{k}_{-}>\beta->\alpha_{\mathrm{s}}$-casein. These differences can be attributed to the differences in the conditions used in each study and in the species and strains used.

Finally, it is also interesting to note the presence in the UHT milk manufactured from raw milk contaminated with $P$. fluorescens after 92 days of several peptides

Table 2 Determination of the peptide bonds cleaved in UHT milk manufactured from raw milk contaminated with $P$. fluorescens after 92 days of storage

\begin{tabular}{|c|c|}
\hline$\beta$-casein & 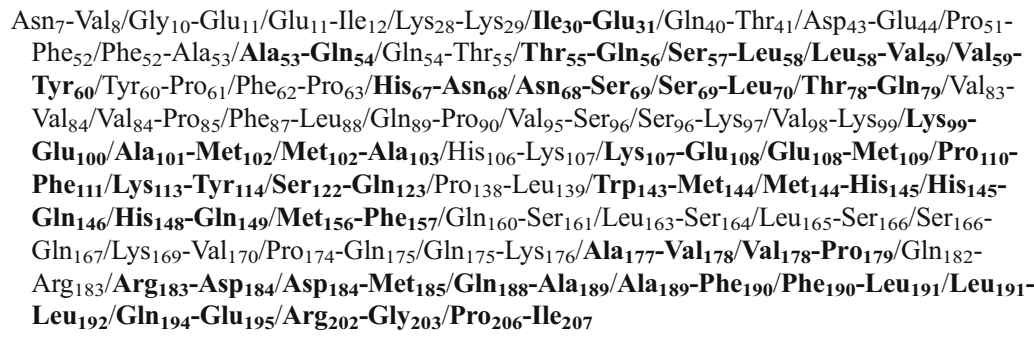 \\
\hline$\alpha_{\mathrm{s} 1}$-casein & 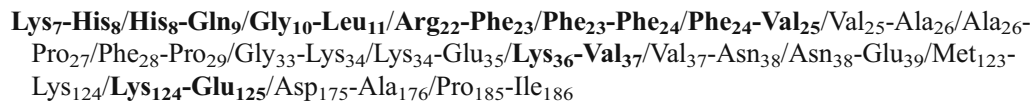 \\
\hline$\alpha_{\mathrm{s} 2}$-casein & Asn $_{162}-$ Phe $_{163} /$ Phe $_{174}-$ Ala $_{175} / \operatorname{Tyr}_{179}-\mathrm{Leu}_{180} / \mathrm{Ala}_{189}-\mathrm{Met}_{190}$ \\
\hline $\mathrm{K}-\mathrm{cc}$ & $\begin{array}{l}\text { Ser }_{\mathbf{1 0 4}} \text {-Phe } \\
\text { Glu }_{158}-\text { Ile }_{159}\end{array}$ \\
\hline
\end{tabular}

This determination was done from the mapping presented in Figs. 6-9. The peptide bonds in bold character were also identified by Nicodème (2006) who studied the proteolysis of purified casein molecules by an extracellular protease from $P$. aureofaciens LBSA1 
coming from K-casein such as K-CN (f105-111), K-CN (f105-112), K-CN (f105-113), K-CN (f106-113), K-CN (f112-123), K-CN (f113-123) and K-CN (f149-169). Cleavage of the peptide bond $\mathrm{Phe}_{105}-\mathrm{Met}_{106}$ in $\mathrm{K}$-casein by these enzymes with the release of para-K-casein and caseinomacropeptide has also been reported using electrophoresis, liquid chromatography and capillary electrophoresis coupled to mass spectrometry (Mitchell and Ewings 1985; López-Fandiño et al. 1993; Miralles et al. 2003; Recio et al. 1996). For example, Recio et al. (2000) identified the proteolysis of the peptide bonds 103-104 and 104-105 of K-casein with a release of K-CN (f98-104) and K-CN (f104-115) fragments by proteases of P. fluorescens B52. In all these cases, the glycosylated part of $\mathrm{K}$-casein was released and the stability of the casein micelles was probably decreased. These results were in accordance with those obtained by several authors indicating that proteases produced by Pseudomonas could have an action similar to chymosin on K-casein (Cousin 1982; Recio et al. 2000; Dairy 2004). This interpretation also agreed with the decrease of zeta potential and hydration (Fig. 3) previously described in this study.

The results obtained with mass spectrometry in this study showed that the number and the type of peptides released were important and various in their origin. It is worth noting that the totality of released peptides was not analysed in this work. The peptides analysed corresponded to only one part of the released peptides, i.e. those present in the NPN fraction. There probably exist other peptides in the NCN fraction (Fig. 4a), but they were not analysed due to the difficulty in using mass spectrometry for the analyses of complex samples such as UHT milk stored for 3 months. For this reason, it is difficult to indicate a clear relationship between instability, physicochemical characteristics of casein micelles and the number and the nature of the peptides released.

\section{Conclusion}

The present study showed that contamination of raw skim milk by $P$. fluorescens CNRZ 798 induced instability in the corresponding UHT milk during storage. This instability was detected by the presence of a sediment, a low value in the phosphate test and the formation of aggregates. These macroscopic instabilities were related to decreases in the negative charge and hydration of casein micelles. The quantitative analyses of the nitrogen fraction showed an abnormal proteolytic pattern. The qualitative analysis of the NPN fraction by reversed phase HPLC (RP-HPLC) combined with ESI/MS/MS revealed that $\beta$-casein was preferentially hydrolysed and that some peptides of the $\mathrm{K}$-casein $\mathrm{C}$-terminal end were also released. The presence of these specific peptides could be responsible for this instability.

These results suggest further perspectives for the investigation of the mechanism of UHT milk destabilisation and the identification of the potential bacteria and enzymes associated with this destabilisation which may be useful to improve milk quality.

Acknowledgements Authors would like to thank CNIEL (National Interprofessional Center of the Dairy Economy) for the financial support, Mr. Daniel Mollé for the discussion about mass spectrometry and Mr. Eric Beaucher for some physico-chemical analyses. 


\section{References}

Adams DM, Barach JT, Speck ML (1975) Heat resistant proteases produced in milk by psychrotrophic bacteria of dairy origin. J Dairy Sci 58:828-834

Adams DM, Barach JT, Speck ML (1976) Effect of psychrotrophic bacteria from raw milk on milk proteins and stability of milk proteins to ultrahigh temperature treatment. J Dairy Sci 59:823-827

Celestino EL, Iyer M, Roginski H (1997) Reconstituted UHT-treated milk: effects of raw milk, powder quality and storage conditions of UHT milk on its physico-chemical attributes and flavour. Int Dairy J 7:129-140

Costa M, Gomez MF, Molina LH, Simpson R, Romero A (2002) Purification and characterization of proteases from Pseudomonas fluorescens and their effect on milk proteins. Arch Latinoam Nutr 52:160-166

Cousin MA (1982) Presence and activity of psychrotrophic microorganisms in milk and dairy products: a review. J Food Protect 45:172-207

Crudden A, Afoufa-Bastien D, Fox PF, Brisson G, Kelly AL (2005) Effect of hydrolysis of casein by plasmin on the heat stability of milk. Int Dairy J 15:1017-1025

Dairy SL (2004) Enzymology. Int J Dairy Technol 57:153-171

Datta N, Deeth HC (2001) Age gelation of UHT milk - a review. Trans IChemE 79:197-210

Datta N, Deeth HC (2003) Diagnosing the cause of proteolysis in UHT milk. Lebensm Wiss Technol 36:173-182

Dufour D, Nicodème M, Perrin C, Driou A, Brusseaux E, Humbert G, Gaillard JL, Dary A (2008) Molecular typing of industrial strains of Pseudomonas spp. isolated from milk and genetical and biochemical characterization of an extracellular protease produced by one of them. Int J Food Microbiol 125:188-196

Fairbairn DJ, Law BA (1986) Proteinases of psychrotrophic bacteria: their production, properties, effects and control. J Dairy Res 53:139-177

Gastaldi E, Trial N, Guillaume C, Bourret E, Gontard N, Cuq JL (2003) Effect of controlled א-casein hydrolysis on rheological properties of acid milk gels. J Dairy Sci 86:704-711

Gaucher I, Mollé D, Gagnaire V, Gaucheron F (2008) Effects of storage temperature on physico-chemical characteristics of semi-skimmed UHT milk. Food Hydrocoll 22:130-143

Gaucher I, Mollé D, Gagnaire V, Léonil J, Rousseau F, Gaucheron F (2009) Destabilisation of commercial UHT milks: proteolysis and changes in milk particles. Milchwissenchaft 64:43-47

Griffin MCA, Griffin WC (1985) A simple turbidimetric method for the determination of the refractive index of large colloidal particles applied to casein micelles. J Colloid Interface Sci 104:409-415

Griffiths MW, Phillips JD, Muir DD (1981) Thermostability of proteases and lipases from a number of species of psychrotrophic bacteria of dairy origin. J Appl Bacteriol 50:289-303

IDF (2001) Milk. Determination of nitrogen content. Part 4: determination of non-protein-nitrogen content, Standard FIL-IDF 20-4. International Dairy Federation, Brussels

Karman AH, Van Boekel MAJS (1986) Evaluation of the Kjeldahl factor for conversion of the nitrogen content of milk and milk products to protein content. Neth Milk Dairy J 40:315-336

Koka R, Weimer BC (2000) Isolation and characterization of a protease from Pseudomonas fluorescens RO98. J Appl Microbiol 89:280-288

Liao CH, McCallus DE (1998) Biochemical and genetic characterization of an extracellular protease from Pseudomonas fluorescens CY091. Appl Environ Microbiol 64:914-921

López-Fandiño R, Olano A, San José C, Ramos M (1993) Application of reversed-phase HPLC to the study of proteolysis in UHT milk. J Dairy Res 60:111-116

Marchand S, Coudijzer K, Heyndrickx M, Dewettinck K, De Block J (2008) Selective determination of the heat-resistant proteolytic activity of bacterial origin in raw milk. Int Dairy J 18:514-519

McMahon DJ (1996) Age-gelation of UHT milk: changes that occur during storage, their effect on shelf life and the mechanism by which age-gelation occurs. In: IDF special issue, heat treatments and alternative methods. International Dairy Federation, Brussels, pp 315-326

Miralles B, Amigo L, Ramos M, Recio I (2003) Analysing para-k-casein and related peptides as indicators of milk proteolysis. Milchwissenschaft 58:412-415

Mitchell GE, Ewings KN (1985) Quantification of bacterial proteolysis causing gelation in UHT-treated milk. N Z J Dairy Sci Technol 20:65-76

Nicodème M (2006) Identification d'une souche de Pseudomonas, bactérie psychrotrophe isolée de lait cru. Caractérisation de sa protéase extracellulaire et des sites d'hydrolyse sur les caséines bovines. Thesis, Université Henri Poincaré, Nancy I, France 
Rajmohan S, Dodd CE, Waites WM (2002) Enzymes from isolates of Pseudomonas fluorescens involved in food spoilage. J Appl Microbiol 93:205-213

Ramsdell GA, Johnson WMT Jr, Evans FR (1931) A test for the detection of milk unstable to heat. J Dairy Sci 14:93-106

Rattray W, Gallmann P, Jelen P (1997) Nutritional, sensory and physico-chemical characterization of protein-standardized UHT milk. Lait 77:279-296

Recio I, López-Fandiño R, Olano A, Olieman C, Ramos M (1996) Study of the formation of caseinomacropeptides in stored ultra-high-temperature-treated milk by capillary electrophoresis. J Agric Food Chem 44:3845-384

Recio I, García-Risco MR, Ramos M, López-Fandiño R (2000) Characterization of peptides produced by the action of psychrotrophic proteinases on K-casein. J Dairy Res 67:625-630

Richardson BC, Te Whaiti IE (1978) Partial characterization of heat-stable extracellular proteases of some psychrotrophic bacteria from raw milk. N Z J Dairy Sci Technol 13:172-176

Smoluchowski M (1917) Versuch einer mathematischen Theorie der Koagulationskinetik kolloider Lösungen. Z Phys Chem 92:129-168

Sørhaug T, Stepaniak L (1997) Psychrotrophs and their enzymes in milk and dairy products: quality aspects. Trends Food Sci Technol 8:35-40

Topçu A, Numanoğlu E, Saldamli İ (2006) Proteolysis and storage stability of UHT milk produced in Turkey. Int Dairy J 16:633-638

Walstra P, Wouters JTM, Geurts TJ (2006) Dairy Science and Technology, 2nd edn. Taylor \& Francis Group, Boca Raton

Wang L, Jayaro BM (2001) Phenotypic and genotypic characterization of Pseudomonas fluorescens isolated from bulk tank milk. J Dairy Sci 84:1421-1429 